\title{
CORPORATE SOCIAL RESPONSIBILITY AND ITS EFFECTS ON SALES VOLUME OF LISTED COMPANIES IN KENYA
}

\author{
Ali Hassan Khamah ${ }^{1 *}$ \\ *1 Department of Business Administration-Kenya Methodist University Tel: +2540722678172
}

*Corresponding Author: -

\begin{abstract}
: -
Corporate social responsibility (CSR) is one of the marketing strategies that are widely used in the industrial field for the purposes of creating customer awareness, enhancing product penetration into the market and boosting firm 's profitability. The study mainly examined the extent to which CSR affect sales volume increase in organizations. The study was in CSR because it is so rich, current, ongoing and challenging. In one way or another, organizations are involved in the CSR as they continue to do business. Many at times, marketers and CSR practitioners in general of various companies have been looking at CSR as just a mere tool for 'social concern' that is, doing it to be seen as "a good neighbour". This perception needs to be erased off from the marketers' minds and a different approach on in handling the CSR must enter the stage with the resolve of strengthening their firms' brand equity.
\end{abstract}

Keywords: - Corporate Social Responsibility, Sales volume, Consumer awareness, Social Concern, Product Penetration, Good Neighbour, Profitability and Brand Equity.

\section{() (\$) (1)}




\section{INTRODUCTION}

It is a fact that CSR is a technique which has and continues to be used in many organizations to communicate with the public indirectly about the existence of a certain firm and its products and/or services being offered. In most cases CSR is carried out as way to show gratitude to the community by giving back. CSR, therefore, is a marketing concept often used in Kenya and indeed globally by many organizations to engage in philanthropic work by giving back to the community aiming at being seen as a good neighbour by the immediate community next to the organization in question. Quite often than not, CSR has been implemented in many organizations majorly to help the society and not the companies necessarily benefiting from the exercise; but only to enhance favourable view of the public (clients or customers) towards that particular firm (Kotler and Armstrong, 2008).

Globally, with businesses focusing on generating profits, sustainability was not a popular concern among companies up until recently. Now, in an era of globalization, multinational corporations and local businesses are no longer able to conduct destructive and unethical practices, such as polluting the environment, without attracting negative feedback from the general public (Jatana and Crowther, 2007). With increased media attention, pressure from non-governmental organizations and rapid global information sharing, there is a surging demand from civil society, consumers, governments, and others for corporations to conduct sustainable business practices (Barkin, 2002). In addition, in order to attract and retain employees and customers, companies are beginning to realize the importance of being ethical while running their daily operations. The corporate response has often meant an adoption of 'a new consciousness', and this has been known as CSR since the 1970s (Hoeffler and Keller, 2002). On the other hand, Sorsa, (2008) argues that in any case, companies are now expected to perform well in non-financial areas such as human rights, business ethics, environmental policies, corporate contributions, community development, corporate governance, and workplace issues. Some examples of CSR are safe working conditions for employees, environmental stewardship, and contributions to community groups and charities. Moser and Miller, (2001) further reveal that the problem is that many companies that claim to be socially responsible often do not live up to such a standard. Because CSR is becoming more commonplace among corporations, there are concerns that some companies promote an image of CSR whether or not they have a true strategy in place and the results to show for. Accountability and transparency are key to conducting business in a responsible manner (Kapoor and Sandhu, 2010).

In Africa, for example, the Nigerian government has come up with a legislation which, if passed, will make it mandatory for companies to pay $3.5 \%$ of their gross profit to corporate social responsibility initiatives (Idemudia, 2011). In Kenya today CSR is well practiced but not as regulated as in Nigeria. There are a variety of organizations doing businesses, ranging from product-oriented marketing and service-oriented marketing. The notable companies that have come out strongly in this initiative of "giving back to the society" are Kenya Airways, Safaricom, Airtel, Kenya Power (KP), East African Breweries Limited (EABL), Kenya Television Networks (KTN), Nation Television (NTV), Co-operative Bank, Equity Bank, Coca Cola, Brookside Dairy, New Kenya Cooperative Creameries (KCC), to mention but a few. All these companies and many others operating in the country in one way or another, do practice CSR. Hence, the area of CSR has been chosen because it is so rich, current, ongoing and challenging. In one way or another, organizations are involved in the CSR as they continue to do the business. If so, what are their goals and objectives of doing so? Are they doing it for sake of doing it or for the purposes of profiting the organization as well? If it is for the purposes of the later, then how best and ethically can it be carried out, to the sense that both parties (a company and customers) can benefit from the concept.

\section{Literature Review}

A useful way of examining the nature of corporate social responsibility is Carroll's four-part model of CSR. Carroll views CSR as a multilayered concept that can be divided into four interrelated concepts that can themselves be further subdivided into four interrelated responsibilities; Economic, Legal, Ethical and Philanthropic. The presentation of these responsibilities is in the form of layers within a pyramid and the full achievement of CSR occurs only when all four layers are met consecutively (Jobber, 2007). Using Carroll's model, Baker, (2000) and Jobber, (2007) recognized that the principal role of a firm was to produce goods and services that people wanted and in so doing be as profitable as possible. Economic responsibilities include maintaining a strong competitive position, operating at high levels of efficiency and effectiveness, and aiming at consistently high levels of profitability. Without the achievement of economic responsibilities, the other three would thus be redundant since the firm would go out of business.

There are varied arguments, for and against CSR programmes. Foster et al, (2009) note that the economists viewed it as a manager's responsibility to generate profits for their shareholders, thus to act in any other way would be a betrayal of this special responsibility. They saw addressing social problems as being the province of government rather than company managers. Economists did not believe that managers should spend other people's money on some perceived social benefit, and thought that to do so was misguided (Michell et al, 2001). Eisingerich et al, (2011) further argue that a corporation's core responsibility is to increase shareholders' value and not to be responsible for societal issues. On the other hand, Bryer, (2010) aver that a corporation can maximize its company value only by voluntarily taking actions on external issues, specifically pollution. The other criticism is that CSR is too costly. Spending of company's money brings with it the lost opportunity to spend the money on other priorities, such as research and development (Moser and Miller, 2001). CSR also encourages consumer cynicism, that is, many consumers regard CSR initiatives as little more than public relations exercises (Jobber, 2007). Furthermore, CSR is a form of risk management in that there are real penalties for companies that are not environmentally or socially responsible. For instance, media criticisms of companies such as Nike, that they involve child labour in the developing countries could be harmful since they could be perceived as being irresponsible 
(Moore, 2001; and Sorsa, 2008). Foster et al, (2009) further observe that apart from the said criticisms, CSR leads to enhanced brand or corporate image and reputation. A strong reputation in environmental and social responsibility can help a company build trust and enhance the image of its brands. Also, if a company is moving to a new area or new market, or enhancing a new site such as distribution centre, store or factory, it helps to be seen as trustworthy and a 'good neighbour' (Kotler and Keller, 2006).

Finally, CSR improves access to capital i.e., organizations that are committed to CSR have access to socially responsible investment (SRI), where investors take into account considerations such as a company's environmental and socially responsible activities. Currently the strength of the arguments for CSR programmes are driving companies increasingly towards the adoption of socially and environmentally responsible strategies (Moser and Miller, 2001). The practice of CSR is subject to much debate and criticism. Proponents argue that there is a strong business case for CSR, in that corporation's benefit in multiple ways by operating with a perspective broader and longer than their own immediate, shortterm profits (Akpan, 2006). Critics, however, argue that CSR distracts from the fundamental economic role of businesses (Amalric et al, 2004 and, Anderson and Bieniaszewska, 2005). Others such as Blowfield and Frynas (2005) and Barrientos (2008) argue that it is nothing more than superficial window-dressing while to some, it is an attempt to preempt the role of governments as a watchdog over powerful multinational corporations. CSR has been redefined throughout the years. However, it is essentially supposed to aid an organization's mission, acting as a guide to what the company stands for and will uphold to its consumers (Arora and Puranik 2004; and Barkin, 2002). Many firms have introduced customer relationship marketing programs to optimize customer interactions. Some marketing observers encourage firms to formally define and manage the value of their customers (Leone et al, 2006). The concept of customer equity can be useful in that regard. Although customer equity can be calculated in different ways, one definition of customer equity is in terms of "the sum of lifetime values of all customers". Customer lifetime value (CLV) is affected by revenue and cost considerations related to customer acquisition, retention, and cross-selling (Barrientos, 2008). Several different concepts and approaches relevant to the topic of customer equity have been put forth.

Lee and Park, (2010); Bond, (2008) and Biggs and Ward, (2004) argue that social responsibility of corporations should be monitored by the state, not corporations whose fundamental principles are the interests of their owners, employees and customers, rather than society as a whole. In this view, a CSR practice by a corporation is a waste of resources, that is, practicing CSR is not a way to maximize resources because the issue lies outside corporate responsibility but within government purview. Finally, the third group of researchers has not found any particular relationship between CSR and a firm's financial performance. They found no particular impact of CSR on risk-adjusted stock return (Amalric et al, 2004). Kluge and Schomann (2008) remark that management initiatives concerning CSR clearly show that companies understand that it is in their own interest to consider public opinion, particularly when it comes to the social and environmental dimensions. Multinational companies (MNCs) are especially vulnerable in this regard, due to the nervous reactions of the stock exchange, public and consumer opinion. In an electronically connected world, the ability to react to developments immediately and wherever one might be representing an ever-present danger to companies that come to be associated with, for example, violating basic rights or some other form of misbehavior. Consequently, there is a strong motivation to take sensitive investor relations seriously and not only in traditional business terms. This is the view held by Arora and Puranik, (2004).

From these studies, three general schools of thought exist; there are those that see a positive, negative, or no relationship between CSR and a firm's financial performance. Therefore, there is no consensus on what constitutes virtuous corporate behavior and as an area of inquiry; CSR is still emerging and very challenging. However, previous researches on CSR have found out that it leads to enhanced corporate image and reputation Foster et al, (2009); Krishnan and Chaudhry, (2007), while Antoni and Portale, (2010) found out that the adoption of good practices of CSR in social cooperatives has a very important role in determining the impact on workers' social capital. A growing body of evidence further asserts that corporations can do well by doing good corporate job (Pohle and Hittner, 2011). Wellknown companies have already proven that they can differentiate their brands and reputations as well as their products and services if they take responsibility for the well-being of the societies and environments in which they operate. These companies are practicing CSR in a manner that generates significant returns to their businesses (Smith, 2010; Porter and Krammer, 2002). Banerjee, (2001) notes that empirical results show that both the adoption of CSR formal instruments and the implementation of a multi-stakeholder ownership are positively related to the creation of social capital intended as cooperative social network, trust, and relational skills.

The profitability argument asserts that doing good (CSR) leads to doing well (improved financial returns). However, the empirical support for this claim is inconclusive (Paul et al, 2010). Kapoor and Sandhu, (2010) maintain that firms already pursuing strategies based on these intangible assets are more likely to use CSRs to enhance these assets than other firms; and firms with already strong reputations or high levels of brand equity are most likely to benefit from the impression of being socially responsible. Lai et al, (2010) on other hand hold that CSR and corporate reputation have positive effects on industrial brand equity and brand performance. However, Godfrey et al, (2010) observe that doing good CSR leads to doing well (improved financial returns).

Furthermore, several studies outlining the theoretical mechanisms that could drive such a relationship have been done, including improved reputation (Moore, 2001), brand equity (Mohr and Webb, 2005; McWilliams and Siegel, 2000), better employee relations (Soch and Sandhu, 2008), or the overall quality of management (Sorsa, 2008; Biggs and Ward, 2004). Firms already pursuing strategies based on these intangible assets are more likely to use CSRs to enhance these assets than other firms, and firms with already strong reputations or high levels of brand equity are most likely to benefit from the 
impression of being socially responsible (Paul et al, 2010). On the other hand Lee and Park, (2010) argue that when CSR is tightly integrated to the management operations, both economic and social targets become easier resulting in improvement in the social and financial performance (in terms of profitability) of the company. These are same sentiments echoed by Porter and Krammer, (2002) and Blowfield, (2004).

Prieto-Carron et al, (2006); Lee and Park, (2010) and Perry and Singh, (2002) hold that CSR increases organization's ability to attract and retain employees, that is, many employees are attracted to employers who are active in social issues. Kapoor and Sandhu, (2010) argue that there is no detrimental impact or penalty from allocation of some resources towards corporate social actions, rather such investments might be beneficial in terms of more profits. Firms should therefore give adequate consideration to their social responsibility (Idemudia, 2011). The managers should not think CSR as an optional activity rather it should be integrated with business strategy like other business issues (McWilliams and Siegel, 2000). This seems to suggest that policy strategy aimed at fostering the adoption of CSR practices by social cooperatives would also positively affect the creation of workers' social capital. To this end, Smith, (2003) and Mandl, (2005) affirm that possible strategies could be the inclusion and adoption of CSR practices among the criteria for obtaining public works contracts that are relevant in social cooperative business and fiscal incentives. Nevertheless, to avoid the risk of perverse incentives, fiscal concessions should be limited to the specific costs strictly connected with the adoption of CSR instruments, such as consultancy or verification costs associated with the implementation of a CSR management system. This view is shared with Barrientos and Smith, (2007), Paul (2001) and United Nations Research Institute for Social Development (UNRISD), (2003).

Furthermore, Young and Thyil, (2009) and Jatana, (2007) argue that CSR is a significant new dimension in organization's rhetoric. But it is clear that organizations vary in their approach to corporate governance and the extent to which a broad view of social responsibility incorporating labour is integrated into values, statements and organizational policies. The importance of recognizing labour as a stakeholder in improving organizational performance has been highlighted by a number of researchers and supported by a range of arguments based on strategy, morals, ethics and relationships. For example, Ite (2004), Idemudia (2011) and Lund-Thomsen (2005) hold this view. On the other hand, Smith, (2010) remarks that CSR influences job satisfaction and employee retention in an organization. It is no secret that many employees consider it a benefit, working for a socially responsible employer (Jenkins, 2005). Aware of this, CSR- engaged employers say employee satisfaction is a major reason behind their CSR efforts. A

PricewaterhouseCoopers survey found that $56 \%$ of employees say attractiveness to employees has a 'considerable impact' on their approach to CSR (Butler, 2006). In addition, attraction of talent, loyalty to a particular firm and employee motivation have all been reasons explaining why CSR can be a source of competitive advantage for a firm (Eisingerich, 2011).

Studies have generated varying results with regard to the effects of CSR on sales volume in an organization. Active debates regarding financial issues of CSR mainly stem from Lee and Park (2010) who assert that a corporation's core responsibility is to increase shareholders' value and not to be responsible for societal issues. Eisingerich et al, (2011) argue that a corporation can maximize its company value only by voluntarily taking actions on external issues, specifically pollution. On the other hand, Mugisa, (2011) found out that there is no direct positive effect noted where an increment in CSR corresponded to an increment in net profit. Rather the opposite was noted where an increase or decrease in CSR activities corresponded to an opposite movement in net profit.

Pohle and Hittner, (2011) remark that today, a surprising number of companies already regard corporate social responsibility as a platform for growth and differentiation. Some brands such as Coca cola, Tusker, Mercedes-Benz, Safaricom etc, have become larger-than-life icons and have maintained their power in the market for years, even generations. High brand equity therefore provides a company with many competitive advantages. A powerful brand enjoys a high level of consumer brand awareness and loyalty (Mohr and Webb, 2005), and because consumers expect stores to carry the brand, the company has more leverage in bargaining with resellers. Since the brand name carries high credibility, the company could have more launch line and brand extensions. A powerful brand offers the company some defense against fierce price competition (Bilson, 2010).

In conclusion, CSR should not be viewed as a drain on resources for carefully implemented CSR policies can help organizations in many ways such as winning new business; increasing customer retention; improving business reputation and standing, and differentiating oneself from competitors among others. This is basically what this research was intended to achieve as knowledge-gap measure.

\section{Objectives}

Specifically, the study is set to achieve the following objectives;

i. To establish the understanding of CSR among company practitioners on sales volume among listed companies.

ii. To assess the effect of CSR on sales volume increase among listed companies.

\section{Hypotheses}

Ho: CSR does not significantly trigger increase in sales volume. HA: CSR does significantly trigger increase in sales volume. 


\title{
Methodology
}

The study adopted a cross-sectional survey research design. A cross-sectional survey research design was appropriate for this study because it involves a close analysis of a situation at one particular point in time to give a 'snap-shot' result and it allows for generalization of information related to the target population (Mugenda, 2008; Collis and Hussey, 2003). The target population of the study consisted 52 quoted or listed companies in Nairobi Securities

Exchange (NSE) (NSE Website, 2012). The 52 respondents of the study were company personnel who were in charge of CSR practices in their organizations. The study adopted a census technique, whereby all companies listed in the NSE were involved in the study. This is because the respondents' number was too small to be sampled and manageable within the constraints of the study (Nassiuma, and Mwangi, 2004; Gupta and Gupta, 2009). The study used primary data collected using questionnaires, which had both unstructured and structured questions. Descriptive and inferential statistics were used to present the findings.

In testing the hypotheses, the study employed Multiple Linear Regression Analysis (MLRA) to examine the effect of CSR on product extensions. The formula for this was;

$$
y_{i}(C I N)=\beta_{0}+\beta_{1} C I \& R D+\beta_{2} H R+\beta_{3} E C+\beta_{4} P C C R+\beta_{5} \mathrm{SR}+\varepsilon
$$

\author{
Where: \\ yi Consumer Increase in Numbers (dependent variable) \\ B0 Constant variable \\ B1 Community Involvement and Rural Development \\ B2 Human Resources e.g., retirement fund benefit plans \\ B3 Environmental Contribution \\ B4 Product Contribution and Customer Relations \\ B5 Shareholders' Relations e.g., payment of dividend to shareholders \\ $\boldsymbol{\varepsilon} \quad$ an error term
}

\section{Analysis and Reporting Response Rate}

Out of 52 questionnaires that were issued to respondents, only 46 were successfully completed and returned for analysis hence giving the study $88.5 \%$ response rate. Those who failed to participate were 6 respondents comprising of $11.5 \%$. Table 1 below demonstrates the response rate.

Table 1: Response Rate

\begin{tabular}{ccc}
\hline Respondents & Number of respondents & Percentage (\%) \\
\hline Expected responses & 52 & 100 \\
Received responses & 46 & 88.5 \\
Un-received responses & 6 & 11.5 \\
\cline { 2 - 3 }
\end{tabular}

\section{Companies' Views on CSR}

In establishing the understanding of CSR among company practitioners on sales volume; the research revealed that $100 \%$ of the respondents held that practicing CSR is very important strategy to use. This is a clear indication that CSR practice will continue being relevant in modern day business. This reveals a positive understanding of CSR among practitioners. The salient concern however, is how significantly it can be done to effectively bring the desired proceeds of sales volume increase to the firms.

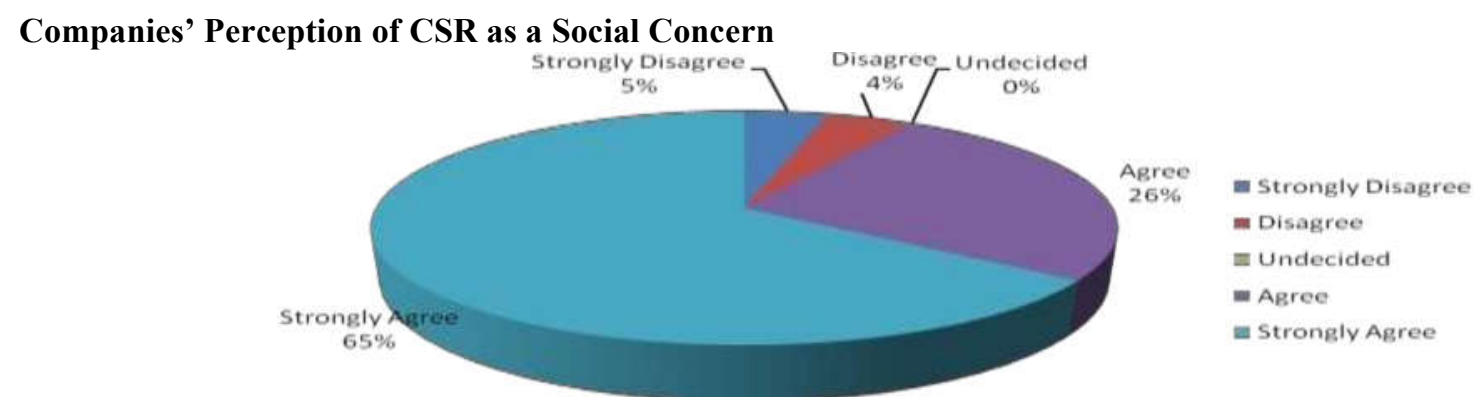

Figure 1: Companies' Perception of CSR as a Social Concern

The study was interested in evaluating the perception held by firms on the effects of CSR on as a social concern. Majority of the respondents, about $65 \%$, strongly agreed that CSR is only done as social concern, whilst $26 \%$ agreed that CSR is mainly executed in firms as a social concern. Those who strongly disagreed with that notion comprised of 5\%, whereas 
4\% just disagreed with the view. This implies that in many companies CSR strategy is only done for the sake of doing it, just to create a good perception among the publics (customers) but not for the purposes of boosting profits in the long run.

\section{Effects of CSR on Company Sales Volume}

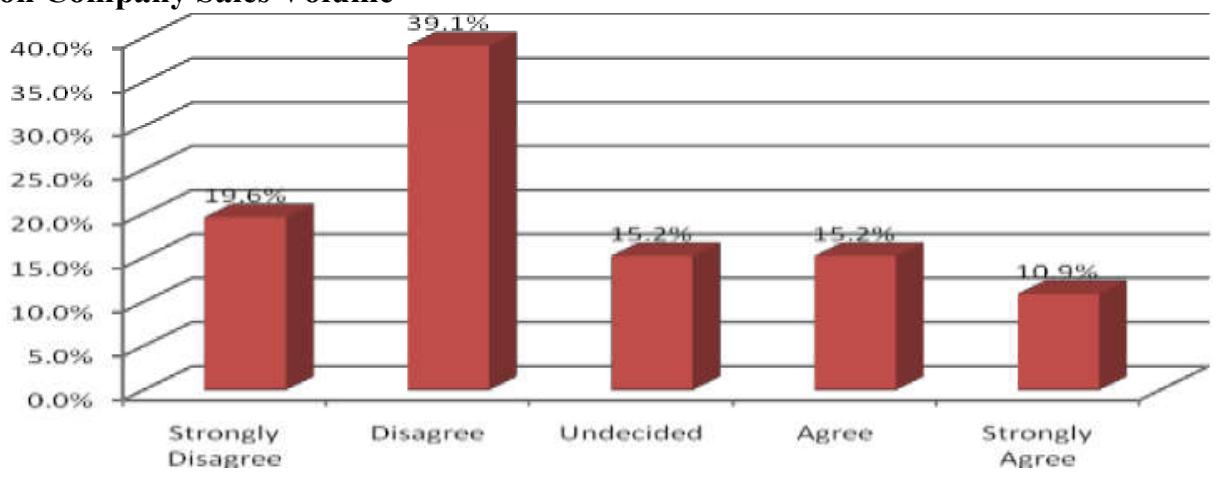

Figure 2: Effects of CSR on Company Sales Volume

In assessing how CSR, when being offered somewhere, affects company sales volume, the results showed that $39.1 \%$ of the respondents disagreed that CSR enhances company sales volume, while $19.6 \%$ strongly disagreed, whereas $15.2 \%$ of the respondents agreed that CSR has an effect on sales volume of a firm, whilst $10.9 \%$ also strongly agreed. However, $15.2 \%$ were uncommitted to the situation. This is alarming because of the big number disagreed, not knowing about the strategy (i.e., $19.6 \%+39.1 \%+15.2=73.9 \%$ ). This calls for proper and aggressive induction on how to apply the strategy both for organizations as well as the society's benefit.

\section{Hypothesis Testing CSR on Increase in Sales Volume}

The null hypothesis was to establish if CSR significantly does not trigger sales volume increase in listed companies. The findings revealed that the entire model had F5, 46=2.206, $\mathrm{P}>.073$ and $\mathrm{R}^{2}=.118$. This showed that there is a weak positive linear relationship between the predictor variables (CSR) and sales volume increase. Table 2 below exhibits the P-value (.073) of sales volume increase as a result of CSR activities in organizations.

Table 2: ANOVA for Sales Volume Increase

\begin{tabular}{ccccccc} 
Model & Sum of Squares & df & Mean & Square & F & Sig. \\
\hline Regression & 2.481 & 5 & & .496 & 2.206 & $.073^{\mathrm{a}}$ \\
Residual & 8.998 & 41 & .225 & & & \\
\hline Total & 11.478 & 46 & & & &
\end{tabular}

a. Predictors: (Constant), SR, PC \& CR, EC, CI \& RD, HR

b. Dependent Variable: Sales Volume Increase

Table 3 below shows the various CSR dimensions understudy and how they scored in terms of their t-tests and p-values on sales volume increase. It is human resources which had a $t=2.155$ and a $p$ value $=.037$, which is strong compared to the rest which had a weak influence on sales volume increase.

Table 3: Effects of CSR on Sales Volume Increase

\begin{tabular}{|c|c|c|c|c|}
\hline CSR Dimensions & Beta & $t$ & Sig. & VIF \\
\hline Constant & 2.245 & 2.843 & .007 & \\
\hline Community & .075 & .511 & .612 & 1.091 \\
\hline $\begin{array}{l}\text { Involvement \& } \\
\text { Human } \\
\text { Resources }\end{array}$ & .354 & 2.155 & .037 & 1.378 \\
\hline $\begin{array}{l}\text { Resources } \\
\text { Environment } \\
\text { Contribution }\end{array}$ & .031 & .217 & .829 & 1.069 \\
\hline $\begin{array}{l}\text { Contribution } \\
\text { Product } \\
\text { Contribution }\end{array}$ & .111 & .756 & .454 & 1.099 \\
\hline $\begin{array}{l}\text { Contribution \& } \\
\text { Shareholder } \\
\text { Relations }\end{array}$ & .099 & .619 & .540 & 1.308 \\
\hline
\end{tabular}

A correlation matrix was carried out to see if predictor variables under study had any or no correlations amongst themselves and thus affecting the outcome of the results. As shown in table 4 below, each outcome variable was significantly 
correlated with each other outcome variable. However, it was noted that shareholder relations and product contribution and customer relations had $\mathrm{r}=-0$. Environmental contribution again with product contribution also had negative correlation of $r=-0.01$. This therefore, implies that CSR has a significant effect on sales volume in listed companies. Thus, the study rejected the null hypothesis and accepted the alternative that indeed CSR does significantly trigger increase in sales volume.

Table 4: Correlations between Predictor Variables with Sales Volume Increase

\begin{tabular}{cccccc} 
& & & EC & PC \& CR & SR \\
\hline CI \& RD & 1 & 0.08 & 0.163 & 0.187 & 0.144 \\
\hline HR & 0.081 & 1 & 0.184 & 0.195 & $.457^{* *}$ \\
EC & 0.163 & 0.18 & 1 & -0.012 & 0.064 \\
PC \& CR & 0.187 & 0.2 & -0.01 & 1 & -0 \\
SR & 0.144 & $.457^{* *}$ & 0.064 & -0.003 & 1 \\
$* * \mathrm{P}_{\leq} 0.01$ & & & & &
\end{tabular}

CI \& RD

HR

\section{Discussion}

The study findings suggest that CSR has statistically significant effect on sales volume increase. In as far as sales volume is concerned, the findings are echoed by Pohle and Hittner, (2011) hold that today, a surprising number of companies regard CSR as a platform for growth and differentiation. Godfrey et al, (2010) assert that good CSR leads to improved financial returns. The essence of these findings is that CSR as a marketing strategy can be relied upon by various company managements to influence on or change their sales volume. What matters, however, is how and when to use the various CSR activities for effective results. This is because CSR alone cannot bring strong positive effects as was found out from the study.

\section{Conclusion}

From the observations made in this study it revealed that in all the companies studied, CSR is being carried out; it was also established that all the managers and/or practitioners consider CSR to be an important marketing strategy to be practiced in organizations. The study further discovered that CSR has a weak positive linear effect on sales volume increase. However, practicing of CSR in a firm is a therefore a tactful balancing act between company profits, consumer needs and societies' interests without compromising any.

CSR is a reliable strategy to be adopted in firms for brand or product enhancement. But since CSR involves a variety of tactics (dimensions or activities), none among them can be used alone to bring desirable proceeds unless they are integrated with the others. It is therefore, imperative to note that apart from combining CSR activities other strategies such as sales promotion, personal selling, advertisement, direct marketing and public relations and publicity should be brought on board. Thus 'coordinated marketing' should be emphasized for successful outcomes in business operations.

\section{Implications}

Based on the findings the following can be recommended;

To the company top management: CSR should be implemented with a different approach of "brand equity building" for the company, as well as taking interests of the society without compromising customer's needs and wants. Managers should drop the mentality that CSR is only done so as to be seen as 'a good neighbour'.

Furthermore, it is imperative upon each company managers to adopt a different approach to CSR implementation through establishing CSR department, instead of combining it with other departments like human resources, public relations and marketing as in the case of many organizations. Doing this will give CSR department autonomy in carrying out the various CSR activities in a more planned, focused and organized way.

To company marketers and public relations managers: For CSR to work effectively and efficiently to produce the desired results in an organization, various CSR dimensions should be integrated. Coordinated marketing should be highly emphasized, whereby the various marketing functions such as sales promotion, brand and product management, personal selling, advertising, direct marketing and public relations and publicity should be integrated. The CSR practitioners should not be too dogmatic emphasizing one CSR dimension or a few over the others.

Since all the forces in the internal, micro and macro-environments matter a lot for successful carrying out of CSR in an organization, it is incumbent upon the marketers to carefully study and monitor the marketing environment to establish whether or not it is conducive for CSR implementation lest it impact negatively on organization's long-term plans.

Finally, managers should also in the first place have passion for CSR for it to work and get embraced fully in the organizations where they work. The support for this should not be wavering or else nothing concrete would be achieved from it (CSR implementation). Thereafter, they should create awareness among their employees on CSR and its role in the concerned company. 


\section{References}

[1].W. Akpan, Between Responsibility and Rhetoric: Some Consequences of CSR in Nigeria's Oil Pronvince.

[2].Development Southern Africa Vol. 23, pp. 223-240, 2006.

[3].F. D. Almaric, Can CSR make Contribution to Solidarity and Quest for Social Justice in the South.

[4].Development Vol. 47, pp. 3-8, 2004.

[5].L.C. Anderson, and L.R. Bieniaszewska, The Role of Corporate Social Responsibility in an Oil Company's Expansion into New Territories. Corporate Social Responsibility and Environmental Management Journal Vol. 12, pp.1-9, 2005.

[6].J.C. Anderson, and J.A., Narus, Business Market Management: Understanding, Creating and Delivering Value, $2^{\text {nd }}$ Edition, Pearson Education, Inc. Patarganj, 2007.

[7].K. Ant, Corporate Social Responsibility Jobs and the Current Financial Crisis. Available at: http://ezinearticles.com/?Corporate-Social-Responsibility-Jobs-and-the-Current-Financial Crisis \& id=1680753 (accessed October 27, 2011), 2008.

[8].G.D. Antoni, and E. Portale, The Effect of Corporate Social Responsibility on Social Capital Creation in Social Cooperatives, Non-Profit and Voluntary Sector Quarterly Vol. 34, pp. 125-131, 2010.

[9].G. Armstrong, and P. Kotler, Marketing an Introduction, (9 ${ }^{\text {th }}$ edition), New Jersey, Pearson Prentice Hall, 2009.

[10]. B. Arora, and R. Puranik, A review of corporate social responsibility in India. Development, Vol.43, pp. 93-100, 2004.

[11]. J. Baker, Marketing Strategy and Management. New York: Palgrave Macmillan, 2000.

[12]. M.J. Baker, and S.J. Hart, The Marketing Book, $6{ }^{\text {th }}$ Edition, Elsevier Ltd, Oxford, UK, 2008.

[13]. B. Banerjee, Corporate Citizenship and Indigenous Stakeholders: Exploring a New Dynamic of OrganizationalStakeholder Relationships. Journal of Corporate Citizenship Vol. 1, pp. 39-55, 2001.

[14]. D. Barkin, The Greening of Business in Mexico: The Greening of Business in Developing Contries: Rhetoric, Reality and Prospect. Zed Books and UNRISD pp. 17-39, 2002.

[15]. S. Barrientos, Contract Labour: 'The Achillis heels' of Corporate Codes in Commercial Value Chains.

[16]. Development and Change Vol.39, pp. 977-990, 2008.

[17]. S. Barrientos, and S. Smith, Do workers benefit from ethical trade? Assessing Codes of Labour Practice in Global Production Systems, Third World Quarterly Vol. 28, pp. 713-729, 2007. Bashar, The impact of perceived CSR initiatives on consumer's buying behaviour: An empirical study, Institute of Management Studies, Dehradun, 2010.

[18]. T. Biggs, and H. Ward, Linking corporate social responsibility, good governance and corporate accountability through dialogue. A Discussion Paper, International Institute for Environment and Development, London $24^{\text {th }}$ December, 2004.

[19]. J. Bilson, Effects of Bad Corporate Social Responsibility, www.businesslink.gov.uk- Accessed on 14/9/2012, 2010.

[20]. M. Blowfield, CSR and Development: Is Business Appropriating Global Justice. Development Vol. 47, pp. 61-68, 2004.

[21]. M. Blowfield, and J.G. Frynas, Setting new agenda: Critical perspectives on Corporate Social Responsibility in the Developing World, International Affairs Vol. 80, pp. 499-513, 2005.

[22]. P. Bond, Social Movement and Corporate Responsibility in South Africa, Development and Change, Vol. 39, pp. 1037-1052, 2008.

[23]. M.C. Branco, and L.L. Rodrigues, 'Corporate social responsibility and resource-based perspectives', [24]. Journal of Business Ethics Vol. 69(2), pp.111-132, 2006.

A. Bryer, Beyond Bureaucracies?: The Struggle for Social Responsibility in the Argentine Workers' Cooperatives. Critique of Anthropology, Vol. 30, pp.411, 2010.

[25]. B.K. Burton, and M. Goldsby, Corporate Social Responsibility Orientation, Goals and Behaviour: A Study of Small Business Owners, Business Society Vol. 48, pp.88, 2009.

[26]. K.M. Butler, 'Examining the Benefits of Corporate Social Responsibility', Employee Benefit News Vol. 20(6), pp.26, 2006.

[27]. P. Cappellin, and G. Giuliani, The Political Economy of Corporate Responsibility in Brazil: Social and Environmental Dimensions: Technology, Business and Society Programme Paper 14. Geneva: United Nations Research Institute for Social Development, 2004.

[28]. D. Cavett-Goodwin, 'Making the Case for Corporate Social Responsibility', Cultural Shifts. Available at: http://culturalshifts.com/archives/181, Accessed on October 27, 2011: 2007.

[29]. L. Cecil, Corporate Social Responsibility Reporting in the United States, McNair Scholars Research Journal1, Vol.1, pp.43-46, 2010.

[30]. W. Chapple, and J. Moon, Corporate Social Responsibility in Asia: A Seven-Country Study of CSR Website Reporting, Business Society Vol. 44, pp.415, 2005.

[31]. K. Chaudhry, and V.R. Krishnan, Impact of Corporate Social Responsibility and Transformational Leadership on Brand Community, Global Business Review. Vol.8, pp20, 2007. 
[32]. A.S. Choi, and E.R. Grey, Socially Responsible Entrepreneurs: What do they do to Create and Build their Companies? Business Horizons, Vol. 51(4), pp.341-352, 2008.

[33]. J. Christensen, and R. Murphy, The Social Irresponsibility of Corporate Tax Avoidance: Taking CSR to the Bottom Line. Development, Vol. 47, pp.37-44, 2004.

[34]. J. Collis, and R. Hussey, Business Research: A Practical Guide for Undergraduate, and Postgraduate Students, $2^{\text {nd }}$ Edition, Basingstoke, Palgrave, Macmillan, 2003.

[35]. S. Dibb, L. Simkin, W.M. Pride, and O.C. Ferell, Marketing Concepts and Strategies, $6{ }^{\text {th }}$ Edition, Cengage Learning EMEA, Hampshire, 2012.

[36]. B. R. Eisingerich, Doing Good and Doing Better Despite Negative Information?: The Role of Corporate Social Responsibility in Cosumer Resistance to Negative Information. Journal of Service Research Vol.14, pp.60, 2011.

[37]. B. G. Eisingerich, G. Rubera, M. Seifert, and G. Bhardwaj, Doing Good and Doing Better Despite Negative Information?: The Role of Corporate Social Responsibility in Consumer Resistance to Negative Information Journal of Service Research 14: 60, 2011.

[38]. M. J. Etzel, B.J. Walker, W.J. Stanton, and A. Pandit, Marketing Concepts and Cases, $13^{\text {th }}$ Edition, Tata McGraw Hill Publishing Co. Ltd. New Delhi, 2008.

[39]. M. K. Foster, A. G. Meinhard, I.E. Berger, and P., Krpan, Corporate Philanthropy in the Canadian Context: From Damage Control Improving Society, Non Profit and Voluntary Sector Quarterly, Vol. 28, pp.441, 2009.

[40]. P.C.Godfrey, W. H. Nile, and J.M. Hansen, Toward a General Theory of CSRs: The Roles of Beneficence, Profitability, Insurance, and Industry Heterogeneity Business Society Vol. 49, pp. 316, 2010.

[41]. C. B. Gupta, and V. Gupta, An Introduction to Statistical Methods, $23^{\text {rd }}$ Edition, Vikas New Delhi, Publishing House, 2009.

[42]. U. IdemudiaCorporate Social Responsibility and Developing Countries: Moving the Critical CSR Research Agenda in Africa Forward. Progress in Development Studies Vol.11, pp.1-25, 2011.

[43]. Ite, U. (2004). Multinationals and Corporate Social Responsibility in Developing Countries: A Case Study of Nigeria. . Corporate Social Responsibilty and Environment Management 11:1-11.

[44]. R. A. Jatana, (2007). Corporate Social Responsibilty and the empowerment of women: An Indian perspective. Social Responsibility Journal Vol. 3, pp.40-48.

[45]. R. Jenkins, Globalization, Corporate Social Responsibility and Poverty, International Affairs Vol. 81, pp. 525-540, 2005.

[46]. D. Jobber, Principles and Practice of Marketing, (5 ${ }^{\text {th }}$ edition), Berkshire McGraw Hill, 2007.

[47]. S. Kapoor, and H.S. Sandhu, Does it Pay to be Socially Responsible? An Empirical Examination of Impact of Corporate Social Responsibility on Financial Performance, Global Business Review Vol.11, pp.185, 2010.

[48]. Kluge, N. and Schömann, I., Corporate Governance, Workers' Participation and CSR: the Way to a Good Company Transfer: European Review of Labour and Research Vol. 14, Vol. 13, 2008.

[49]. P. Kotler, and G. Armstrong, Principles of Marketing, (12 ${ }^{\text {th }}$ edition), New Jersey, Pearson Prentice Hall, 2008.

[50]. P. Kotler, and K.L. Keller, Marketing Management, (12 ${ }^{\text {th }}$ edition), New Jersey, Pearson Prentice Hall, 2006.

[51]. C. S. Lai, Chui, C. J., C.F. Young, and D.C. Pai, The effect of Corporate Social Responsibility on Brand Performance: The Mediating Effect on Industrial Brand Equity and Corporate Reputation. Journal of Business Ethics Vol.95, pp. 457-469, 2010.

[52]. Lambardo, The Role of Corporate Social Responsibility in Consumer Behaviour: An Unresolved Paradox: A Published Research Paper University of Calabria, Italy, (2011).

[53]. Lee, and S.Y. Park Financial Impacts of Socially Responsible Activities On Airline Companies, Journal of Hospitality \& Tourism Research Vol. 34, pp.185, 2010.

[54]. R. P. Leone, V.R. Rao, K.L. Keller, A.M. Luo, L. McAlister, and R. Srivastava, Linking Brand equity to Customer Equity, Journal of Service Research Vol.9, pp.2, 2006.

[55]. R. R. Leone, Linking Brand Equity to Customer Equity. Journal of Service Research Vol. 9, pp.2, 2006.

[56]. Lund-Thomsen, Corporate Accountability in South Africa: The Role of Commmunity Mobilizing in Enviromental Governance. International Affairs Vol.81, pp.581-598, 2005.

A. Mandl, CSR Competitiveness European SME's Good Practice, KMU Forschung Austria,Austrian Institute for SME Research, pp. 29-35,2005.

[57]. R. Mason, D.A. Lind, and W. G. Marchal, Statistical Techniques in Business and Economics, (10 ${ }^{\text {th }}$ edition), Atlanta, Irwin McGraw Hill, 1999. 
A. McWilliams, and D. Siegel, 'Corporate Social Responsibility and Financial Performance: Correlation or Misspecification?’ Strategic Management Journal, Vol. 221(5), pp.603-609, 2000.

[58]. P. Michell, J. King and J. Reast, Brand Values Related to Industrial Products, Industrial Marketing Management, Vol. 30(5), pp.415-425, 2001.

[59]. L.A. Mohr, and D.J. Webb, 'The Effects of Corporate Social Responsibility and Price on Consumer Responses', Journal of Consumer Affairs, Vol. 39(1), pp.121-47, 2005.

[60]. G. Moore, Corporate Social and Financial Performance: An Investigation in the UK Supermarket Industry, [61]. Journal of Business Ethics Vol. 34(3/4), pp. 299-315, 2001.

[62]. T. Moser, and D. Miller, Multinational Corporation Impacts on the Environment and Communities in the Developing World: A synthesis of the Contemporary Debate, Business Society, Vol. 37, pp. 333-343 2001.

A. G. Mugenda, Social Science Research, Theory and Principles: Applied Research and Training Services, Nairobi, Longhorn Publishers, 2008.

[63]. J. Mugisa, The Effect of Corporate Social Responsibility on Business Operations and Performance, Published Research Project, Martyrs University Nkozi, Uganda, 2011.

[64]. D.K. Nassiuma, and W.J. Mwangi, Statistical Methods for Information Analysis, Njoro, Egerton University Press, 2004.

[65]. C. G. Paul, W. H. Nile and J. M. Hansen, Toward a General Theory of CSRs: The Roles of Beneficence, Profitability, Insurance, and Industry Heterogeneity, Business Society, Vol. 49, pp. 316, 2010.

[66]. C. N. Paul, Toward a General Theory of CSRs: The Roles of Beneficence, Profitability, Insurance and Industry Haterogeneity. Business Society Vol. 49, pp. 316, 2010.

[67]. K. Paul, An Empirical Investigation of the Relationship between Change in Corporate Social Performance and

Financial Performance: A Stakeholder Theory Perspective. Journal of Business Ethics, Vol. 32(2), pp. 143-156, 2001.

[68]. J. Peloza, and J. Shang, Investing in Corporate Social Responsibility to Enhance Customer Value, http://law.harvard.educ/corpov-Accessed on 8/11/2013, 2011.

[69]. M. Perry, and S. Singh, Corporate environmental responsibility in Singapore and Malaysia: Zed Books and UNRISD, pp. 97-128, 2002.

[70]. G. Pohle, and J. Hittner, Attaining Sustainable Growth through Corporate Social Responsibility Impact for Business: From cost to Growth. IBM Institute for Business Value, Vol. 46:45-98, 2011.

[71]. M.E. Porter, and M.R. Krammer, 'The Competitive Advantage of Corporate Philanthropy', Harward Business Review, Vol. 80(12), pp. 56-68, 2002.

[72]. M. Prieto-Carron, P. Lund-Thomsen, A. Chan, A. Muro, and C. Bhushan, Critical perspective on CSR and development: What we know, what we don't know and what we need to know, International Affairs, Vol. 82, pp. 977-987, 2006.

[73]. A.R. Rahim, F.W. Jalaludin and K. Tajuddin, The Importance of Corporate Social Responsibility on Consumer Behaviour in Malaysia, Asian Academy Management Journal, Vol. 16 (1), pp. 119-139, 2011.

[74]. Sharp, J. Coporate Social Responsibility and Development: An Anthropological Perspective,. Development Southern Africa Vol. 23, pp. 213-222, 2006.

[75]. A.D. Smith, Growth of corporate social responsibility as a sustainable business Strategy in difficult financial times, International Journal of Sustainable Economy, Vol.2, pp.1-59, 2010.

[76]. C.N. Smith, Corporate social responsibility: Whether or how? California Management Review, Vol. 45, pp. 5276, 2003.

[77]. H. Soch, and H.S. Sandhu, 'Does Customer Relationship Management Activity Affect Firm Performance?' [78].

Global Business Review, 9(2):189-206, 2008.

[79]. M. M. Solomon, Marketing Real People, Real Choices. New Jersey: Pearson Prentice Hall, 2009.

[80]. M. R. Solomon, G.W. Marshall, and E.W. Stuart, Marketing Real People, Real Choices, New Jersey, Pearson Prentice Hall, 2009.

[81]. V. Sorsa, How to Explain Socially Responsible Corporate Actions Institutionally: Theoretical and Methodological Critique, Electronic. Journal of Business Ethics and Organizational Studies, Vol. 13, pp. 32-41, 2008.

[82]. United Nations Research Institute for Social Development (UNRISD), Corporate Social Responsibility and Development: Towards a New Agenda? Date $17^{\text {th }}-18^{\text {th }}$ November, Geneva, 2003.

[83]. B.W. Werther, and D. Chandler, Strategic Corporate Social Responsibility as Global Brand Global Business Review, Vol. 7, pp.160-176, 2005.

[84]. S. Young, and V. Thyil, Governance, employees and CSR: Integration is the Key to Unlocking Value, Asia Pacific Journal of Human Resources Vol. 47, pp. 167, 2009.

[85]. M. Veerapongi, The effect of Corporate Social Responsibility on Customer Loyalty, [86]. International Academy of Business and Economics, Vol. 11 (2), pp. 240-290, 2011.

[87]. A.C. Van Riel, C.P. Mortanges, and S. Straukens, Marketing Antecedents of Industrial Brand Equity: An empirical Investigation in Specialty Chemicals. Industrial marketing Management, Vol. 34(4), pp. 841- 847, 2005. 